\title{
FORTHCOMING
}

Contributions in the March and subsequent issues include:

Abraham Ascher, "Axelrod and Kautsky"

Andrzej Korbonski, "The Polish Communist Party, I938-i942"

ImRE BobA, "The Episcopacy of Saint Methodius"

Henry L. Eaton, "Cadasters and Censuses of Muscovy"

Frank R. Silbajoris, "Narrative Conceptions in the Lyrics of Fet"

DISGUSSION SECTION

"The Soviet Union and Modernization." Key paper by Alfred Meyer, with comments by John Kautsky, Dan Jacobs, and Robert Sharlet. John A. Armstrong, chairman.

The Index to Volume XXV (1966) and the volume contents will appear in the March 1967 issue.

\section{Change of Address}

The editorial offices of Slavic Review were moved as of August I 7, I966, from 409 West I 7 Street, New York, New York 10027 to:

622 West I 3 STreet

COLUMBIA UNIVERSITY

NEW YORK, NEW YORK I0025 


\section{RUSSIAN INTELLECIUAL HISTORY An Anthology}

Edited by MARC RAEFF, Columbia University

With an Introduction by ISAIAH BERLIN

The first volume in the Harbrace Series in Russian Area Studies, this anthology presents basic political and social documents of the eighteenth- and nineteenth-century Russian intelligentsia. The editor has chosen 24 essays by 19 writers of the pre-Soviet period, which reveal the process of reasoning and the framework of analysis that led to the creation and acceptance of ideas.

Paperbound

404 pages

$\$ 4.50$

\section{HISTORY OF \\ EUROPEAN CIVILIZATION LIBRARY}

General Editor: GEOFFREY BARRACLOUGH

This series of short paperbound textbooks makes available to American students important new studies by distinguished British and European scholars. Invaluable supplementary reading for Western Civilization and European history courses, the books cut across the traditional divisions of nations and periods and focus attention on major movements and influences that need to be considered afresh.

THE RISE OF CHRISTIAN EUROPE

Hugh Trevor-Roper

216 pages

$\$ 2.45$

REFORMATION AND SOCIETY

IN SIXTEENTH-CENTURY EUROPE

A. G. Dickens

216 pages

$\$ 2.95$

THE EVOLUTION OF RUSSTA

Otto Hoetzsch

214 pages

$\$ 2.95$

FROM SARAJEVO TO POTSDAM

A. J. P. Taylor

216 pages

$\$ 2.95$

Coming in the Spring

BYZANTIUM AND EUROPE Speros Vryonis

THE ANCIEN RËGIME C. B. A. Behrens

Harcourt, Brace \& World, Inc.

New York/Chicago/San Francisco/Atlanta 